\title{
War Resistance and Moral Experience
}

by John R. Mergendoller. Unpublished Doctoral Dissertation,

The University of Michigan, 1981.

Reviewed by

Gregory Baum

St. Michael's College,

University of Toronto

In his dissertation, J. R. Mergendoller tries to clarify the nature of moral action by examining the resistance of young Americans to the Vietnam War. The dissertation was written in a department that emphasized the scientific method in the study of morality and recommended the research methods devised by Kohlberg and other cognitive-developmentalists. The author of the dissertation distrusted this approach. He was dissatisfied with the emphasis on quantification, the impersonal style of interviewing and filling out questionnaires, the laboratory atmosphere, the filtering of information through antecedently devised categories, and so forth. At the same time he could not leave the Kohlberg school behind him altogether. So he decided to argue with it. He turned to a phenomenological approach in the hope that his results would allow him to offer a substantial criticism of the Kohlberg school.

Mergendoller decided to engage in prolonged conversation with a small sample of war resisters, with men who had resisted the draft for moral reasons. In his interviews he also administered the Kohlberg test to them. The purpose of these conversations was to reconstitute the history of their resistance to the war. The questions Mergendoller posed were designed to help his partners to recall the details and recover the total drama of their moral decision and its consequences. Eventually he decided to present five of these case histories in detail. These five chapters constitute the body of the dissertation. It is preceded by two chapters on methodology and followed by two chapters of reflections and conclusions.

Before reporting on the author's insights, I wish to look more closely at the methodology used by him. Mergendoller suggests that there are two uses of phenomenology in social science research. The first he calls "description." Here the researchers offer a detailed description of the phenomenon, using their empathy and all their sensitivities as organs of perception in the hope that this prolonged and intimate contact with the phenomenon will disclose something of its nature. The second use is "analysis." Here description is only the first 
phase: the second phase is the introduction of analytical categories that allow the researchers to order and interrelate their data and arrive at new insights and perspectives. The author argues that there need be no contradiction between these two uses. The descriptive phase may suggest to the researcher the categories that deserve attention and may profitably be used in the analysis.

Mergendoller's method reminds one of the work of Richard Sennett, in particular of the brilliant book he wrote with Jonathan Cobb, The Hidden Injuries of Class, where a phenomenological approach was applied to the study of a few workers, coupled with an analytical phase. This approach produced insights into working class America that had escaped many sociological studies. The method was fruitful.

This method also has its shortcomings. It works only if it is well done. What is required of the researcher is a humanistic background, a familiarity with the poetic dimension of language, and a certain creative flair which scientific training cannot communicate. The same method in the hands of a less gifted practitioner would offer little that is new or interesting. Yet even when such research is well done, the reader keeps wondering whether this method is simply an imaginative form of literary criticism applied to a few interesting conversations, or whether it provides a sound basis for more generalized statements that command scientific attention.

In my opinion Mergendoller has used the phenomenological method creatively and arrived at significant insights. He has written a very interesting dissertation. I enjoyed reading his work. Before mentioning some of the questions raised by the dissertation, I wish to summarize his insights into the moral experience of the war resisters.

Reflecting on the five stories of war resisters, Mergendoller introduces a useful distinction between two kinds of involvement, the "empathic involvement" of the impassioned spectator who is in solidarity with the victims of war or oppression and the "agentic involvement" of the person who is, or is about to become, an agent in the machine that produces war or oppression. In the war resisters he interviewed, the author found that their resistance came about as they moved from being spectators vaguely disapproving of the war to being drafted to become soldiers fighting the war. These men were not conscientious objectors who refused to become soldiers; they became conscientious objectors as they saw themselves becoming soldiers and experienced revulsion at this. Their moral resistance was not a response to the war, but a response to those things they would be required to do in the war. It was not abstract moral reasoning, not the kind of reasoning studied by Kohlberg, 
that led to resistance; it was rather the refusal to do what is wrong. Reflection came later. Only as they had to file their Claim for Conscientious Objector Status did they try to formalize their reasoning in a more abstract manner. Mergendoller speaks here of the primacy of action.

The author shows, moreover, that the kind of reasoning that guided these men in their action was not ethical reflection on the nature of the war or the weapons used in it, but ethical reflection on the kind of person they wanted to be. The author calls this "self-definition." The young men refused the draft because they did not want to become killers. They felt that by becoming soldiers they were making themselves into the kind of person they did not want to be.

The moral experience of the war resisters, Mergendoller concludes, totally escapes the categories used by the cognitive-developmentalists in the study of moral action. Reason plays a role in moral experience, but it is a reason linked to feelings of attraction and revulsion, and generated by reflection on action.

These are interesting insights. What seems curious to this reviewer is that Mergendoller did not enter into dialogue with moral philosophy. For him the turn to phenomenology was a way of escaping the rationalism that marks the study of morality in some university departments. But when he formulates his conclusions at the end, he enters the field of moral philosophy without an extended acquaintance with it. Thus he rashly advocates a separation of feeling from thinking, and of acting from thinking, for which his detailed research and his special insights have given him no warrant whatever. It is also puzzling why the author regards the resistance to the war as the model for all moral experience. It does not seem to occur to him that, as there are many types of religious experience, there are also many types of moral experience. Puzzling also is the easy distinction adopted by the author between moral resistance to the war on the one hand and religious and political resistance on the other. Religious and political reasons for resisting the draft were surely grounded in experience and nourished by a vision that had a moral dimension.

Despite these unresolved questions Mergendoller's dissertation is a useful study of contemporary relevance. For the moral experience of the young men who resisted the war in Vietnam resembles a moral experience common in our day that has received little philosophical or scientific attention. I am speaking of the moral experience of persons of compassion in solidarity with the victims of North American society. As North American society hardens itself, becomes increasingly indifferent to hunger and oppression in the Third World, reconciles itself with a politics that protects the privileges of the suc- 
cessful, and tightens the wires that lock the unsuccessful at home into ever expanding cages of poverty and impotence, persons of compassion, whether religious or secular, are becoming more and more anguished. As such persons discover that they are not simply impassioned spectators but, because of the privileges they enjoy, are also agents in the machine that causes oppression, they find themselves in a situation that resembles that of the war resisters, except that they are not certain of what "opting out" would mean for them. The moral dilemma of our time is how to live ethically in a cruel world. Mergendoller's study of war resisters provides inspiration and offers some categories that may help contemporaries to gain a better understanding of their moral experience. 